УДК 502.171(470.44)

\title{
ИСТОРИЯ ФОРМИРОВАНИЯ СЕТИ ОСОБО ОХРАНЯЕМЫХ ПРИРОДНЫХ ТЕРРИТОРИЙ САРАТОВСКОЙ ОБЛАСТИ
}

\section{Ю.В. Волков}

Саратовский государственный университет, кафедра физической географии и ландшафтной экологии E-mail: VolkovUV@info.sgu.ru

В статье рассмотрена история формирования региональной сети ООПТ Саратовской области, выделены периоды и этапы в её развитии, проанализирована региональная специфика подходов к организации и выявлению ООПТ. В результате проведенных исследований автором делается вывод о необходимости скорейшего развития сети ООПТ Саратовской области, отвечающей современным требованиям, главное из которых - обеспечение экологической стабильности в регионе.

History of Formation of a Network of Particularly Protected Natural Territories (PPNT) of the Saratov Region

\section{Yu.V. Volkov}

The history of formation of a regional network of PPNT of Saratov area is considered, in the article the periods and stages in its development are allocated, are analysed regional specifity of the approaches to organization and revealing PPNT. As a result of the carried out researches the author judges necessity of the prompt development of a network PPNT of Saratov area adequate the modern requirements, main of which - maintenance of ecological stability in region.

\section{Постановка проблемы}

В настоящей статье рассмотрена история формирования особо охраняемых природных территорий (ООПТ) Саратовской области в период с 90-х гг. XIX в. до конца XX века. Основной целью исследования являлось выявление исторических периодов в развитии региональной сети ООПТ Саратовской области, изучение их своеобразия. Актуальность работы связана с очередным этапом социально-экономического развития страны в целом и Саратовской области в частности, совершенствованием современной концепции региональных систем ООПТ. Поэтому ныне требуется обобщение регионального опыта по созданию системы охраняемых природных территорий для оценки современного их состояния и определения направлений будущего развития, в частности для Саратовской области. Следует отметить, что представленное исследование, насколько известно, является первым, содержащим наиболее полные сведения по истории формирования ООПТ Саратовской области.

\section{Факторы и периоды формирования сети ООПт Саратовской области}

Современный облик региональной сети ООПТ Саратовской области сложился под действием различных факторов. Их можно разделить на три группы: природно-ландшафтные (преобладание степей, равнинность территории региона и др.); социально-экономические (высокая степень сельскохозяйственной освоенности, наличие двух волжских водохранилищ и др.); научные исследования в сфере охраняемых природных территорий, характер и направление которых определили практику выявления и организации ООПТ в Саратовской области. Данные факторы выявляют характерные инди-

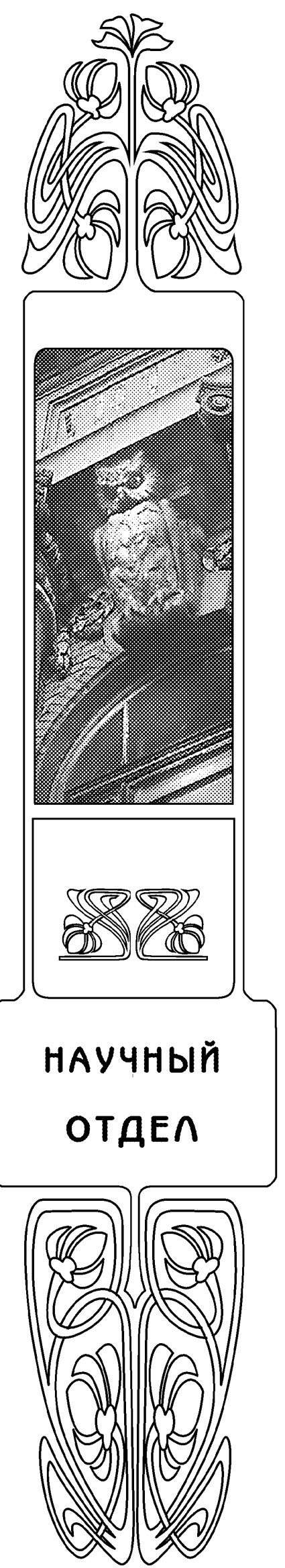


видуальные черты становления сети охраняемых природных территорий региона. В то же время в истории формирования сети ООПТ Саратовской области закономерно проявляются общие тенденции развития, характерные для многих регионов и России в целом. Связаны они как с изменением общегосударственной политики по охране окружающей среды, эволюцией научных представлений о роли и функциях ООПТ, так и с социально-экономическим развитием сходных по природно-ландшафтным условиям регионов.

История организации ООПТ в нашей стране имеет глубокие корни. Как отмечает Ф.Р. Штильмарк, организация первых охраняемых природных территорий была, вероятно, вызвана двумя причинами: во-первых, необходимостью рационального использования, прежде всего, лесных и охотничьих ресурсов; во-вторых, религиозным, эстетико-культовым отношением к природе $[1,2]$. В предложенной статье не рассматривается данный период в истории становления ООПТ Саратовской области. Подобная информация, несомненно, была бы полезна для понимания региональных нравственно-этических начал организации праобразов ООПТ, а также, возможно, позволила бы установить ряд характерных для этого периода черт природопользования на конкретных территориях Саратовской области. Однако данная проблема, по нашему мнению, заслуживает отдельного изучения.

В истории формирования современной сети ООПТ Саратовской области могут быть выделены два основных периода, каждый из которых, в свою очередь, состоит из двух этапов. Основными критериями выделения периодов и этапов формирования сети ООПТ Саратовской области, прежде всего, являлось изменение подходов к определению, выявлению особо охраняемых территорий, а также появление новых категорий в сети ООПТ региона.

Первый период охватывает временной отрезок с конца XIX до середины XX века. В этот период, благодаря бурной активизации общероссийского природоохранного движения, а также становлению представлений об ООПТ и их роли в деле охраны природы, появляются первые особо охраняемые территории Саратовской области.

Второй период связан с деятельностью Саратовского областного отдела Всероссийского общества охраны природы. Он начинается со второй половины прошлого века и заканчивается в 90-е годы. Это период активного формирования сети особо охраняемых природных территорий Саратовской области, первым элементом которой следует считать охотничьи заказники, появившиеся в 60-е гг. XX века [3]. Именно с организации первых комплексных и видовых охотничьих заказников в Саратовской области начинается процесс формирования современной структуры региональной сети ООПТ Саратовской области.

\section{Характеристика периодов и этапов формирования сети ООПт}

Первый период, первый этап - конец XIX 20-е гг. XX века.

Начало первого этапа связано с появлением в конце XIX в. в дореволюционной России частных заповедников, самый известный из которых «Аскания-Нова», организованный Ф.Э. ФальцФейном [2]. Подобными частными заповедниками были участки целинных степей в имении Карамзиных (Самарская губерния) и в имении графини Паниной в Валуйском уезде (Воронежская губерния), а также часть имения князя Вяземского в Тамбовской губернии $[2,4]$. В имении Ровинка Черноярского уезда Астраханской губернии его владельцем - помещиком А.П. Ровинским был фактически организован охотничий заказник. Вот что пишут современники о Ровинском и режиме охраны фауны в его имении: «А.П., сам охотник в юности, оставляет эти привычки “кровавого спорта" - и, в качестве землевладельца ста квадратных верст, делается усердным охранителем всего живого, зверья пернатого и пушного в своих угодьях. Особенно полезные птицы и звери неприкосновенны. Охота, бесцельный убой, запрещена даже родному сыну - и только на дичь, и только в известное время, и только с особаго разрешенія, можно охотиться» $[5$, с.7]. Отметим, что А.П. Ровинский был членом-учредителем Саратовского общества естествоиспытателей и любителей природы; им были собраны минералогическая коллекция, впоследствии переданная в музей общества естествоиспытателей, гербарий и некоторые виды насекомых Астраханской губернии. В окрестностях с. Ровинки А.П. Ровинским были раскопаны золотоордынские курганы и собраны археологические находки [5].

В Саратовской губернии частный заповедникзаказник был организован владельцем имения Пады Балашовского уезда В.Л. Нарышкиным на территории небольшого соснового леска вблизи деревни Рзянка, имевшего название Борок. Борок представлял собой произрастающий в долине р. Хопер сухой бор - остаток более крупного лесного массива. Его площадь составляла 14 десятин. Следует отметить, что В.Л. Нарышкин, как и А.П. Ровинский, интересовался природными особенностями своего имения. По его инициативе и на его средства было организовано естественноисторическое исследование имения. Исследование было проведено ботаником В.А. Траншелем, геологом П.А. Замятченским, зоологом А.А. Силантьевым под научным руководством профессора В.В. Докучаева [6]. Благодаря этому исследованию ученые смогли дать подробную характеристику природных условий имения и получить некоторые сведения об особенностях использования и состояния его земель. В частности, исследователями отмечается, что первозданный облик степей сохранился лишь по склонам балок и оврагов, 
на безлесных водоразделах господствуют лишь залежи различного возраста, а леса имеют сильно изреженный и сильно измененный в породном отношении вид. В некоторых частях имения Пады, как указывается А.А. Силантьевым, сохраняется залежная система земледелия, как и у смежных с имением крупных землевладельцев, в то же время крестьянские хозяйства используют трехпольную систему земледелия. По мнению А.А. Силантьева, трехпольная система хозяйства оказывает большее влияние на природу, чем залежная, «...при которой только и возможно сохранение степей, а вместе и их фауны, в состоянии, несколько подходящем к первобытному» [6, с. 392]. Этот факт свидетельствует о наличии в крупных имениях достаточного земельного фонда, позволяющего сохранять залежную систему хозяйства.

Учитывая вышеизложенное, можно предположить, что у крупных землевладельцев Саратовской губернии описываемого периода, имевших значительные земельные ресурсы, могли существовать небольшие территории со статусом заповедных, соответствующих современному охранному режиму заказников. Еще одно подтверждение нашему предположению находим в статье В.И. Талиева (1898 г.), посвященной флоре Саратовской губернии. В ней автор, описывая свой путь от с. Поповка Саратовского уезда до г. Хвалынска, указывает «на большую непрерывную площадь» лесов [7, с. 2]. По мнению В.И. Талиева, сохранение значительных площадей лесов в этом районе - заслуга крупных владельцев.

Вероятнее всего, заказной или заповедный режим на каких-либо территориях мог организовываться вокруг центральной усадьбы помещика, а также в приграничных частях имения.

В конце XIX - начале XX в. основой экономического развития Саратовской губернии является сельское хозяйство, характеризующееся ярко выраженной направленностью - зерноводством. Экстенсивное освоение земельных ресурсов за счет расширения посевных площадей привело к увеличению земель, отводимых под пашню. По темпам их роста Самарская и Саратовская губернии занимали соответственно первое и второе места в Поволжье. В Саратовской губернии посевная площадь увеличилась с 1896 по 1913 г. на $23 \%$ [8]. Таким образом, размеры распаханности земель Саратовского Правобережья сравнялись с Центральным земледельческим районом. Быстрый рост освоения земель происходил в основном в южных уездах Правобережья и в Заволжье, где еще оставался фонд государственных неосвоенных земель. Освоению под пашни подверглись и земли, ранее считавшиеся «неудобными», происходила распашка лугов, пастбищ. Так, в Новоузенском районе площадь сенокосов сократилась с 323 до 89 тыс. десятин [8]. Преобладала трехпольная система земледелия, а на юге Заволжья - залежная, оставляющая обширные пространства разновозрастных залежей. Высокий темп освоения земельных ресурсов Саратовской губернии, а также общероссийский экономический кризис конца XIX в., возникший из-за перехода от феодальных к капиталистическим отношениям, повлияли на еще более интенсивное использование природных ресурсов. Данные события повлекли за собой уничтожение отдельных степных видов растений и животных и значительное сокращение степных геосистем. Отметим, что к этому периоду лесные геосистемы претерпели еще более существенные изменения. Значительное количество лесов, как отмечают многие исследователи того времени, в пределах Саратовской губернии было вырублено [9].

Яркий пример лесопользования в пределах волжского займища Нижней Волги (Астраханская и Саратовская губернии) с детальной характеристикой всех её особенностей находим у Г.И. Лакина в большой статье, опубликованной в нескольких выпусках «Сельско-хозяйственного вестника Юго-Востока» [10]. В одной из частей своей статьи, посвященной охране леса в крестьянских общинах, Г.И. Лакин пишет: «Общественники вырубали свои леса безпощадно, рубили везде и лес всякого возраста, во все времена года, рубили днем, рубили ночью, рубили взрослые, рубили и малые. Рубили нуждающиеся и богачи, рубили все друг перед другом, кому была охота и возможность. Рубили лес везде, где бы он не появился, рубили и под землю и на койлы разных размеров, кому как удобнее, кому как охотнее. $<\ldots>>$...В некоторых Обществах, по приговору, какая-нибудь часть леса объявлялась “заповедною”. “Заповедь” лесов иногда обставлялась торжественно. Лес, предназначенный к заповеди, обходился кругом всенародно священником с иконою, с пением молитв; служился соответственный молебен» $[10$, с.15]. Срок «заповеди» устанавливался обычно на 10 лет, иногда 15, очень редко на более долгий срок. Со временем из «заповеди» под видом сбора сушняка «начинали потаскивать и кол, пряча его в возу между сушником» [10, c.15]. Постепенно заповедный лес истощался от самовольных порубок. И наконец, на сходе решали вырубить до срока весь заповедный лес. Далее Лакин пишет, что заповедных лесов среди казачьих и крестьянских лесов волжского займища нет. И приводит две основные причины отсутствия таких лесов. Первая - бесконечные нарушения, которые случаются вопреки запрету, а вторая - появление упрощенных планов лесоустройства, позволяющих регулировать лесопользование [10].

Таким образом, указанные выше факты свидетельствуют, что на территории Саратовской губернии в описываемый временной период наиболее вероятным следует признать существование ООПТ заказного типа преимущественно в лесных ландшафтах. Их основная роль сводилась, прежде всего, к регулированию лесопользования, а также сохранению наиболее ценных лесных 
массивов в малоиспользуемых помещичьих землевладениях.

Второй этап формирования ООПТ в Саратовском крае (20 - 50-е гг. XX в.) происходит на фоне дальнейшего роста общероссийского природоохранного движения. В начале XX в. организуются первые государственные заповедники - Баргузинский, Саянский, «Кедровая Падь» [2]. После 1917 г. охрана природы вышла на новый более интенсивный виток развития. В эпоху становления советской власти и формирования СССР развитие природоохранного движения нарастает. С отменой частной собственности на землю быстро создается и развивается сеть первых советских заповедников [11]. В первые годы становления советской власти их число постоянно растет, в то же время частные заповедники были фактически ликвидированы [4].

Второй этап связан с подъемом краеведческой деятельности различных направлений в Саратовском крае в начале XX века [12]. Ещё в конце XIX в. создаются Саратовская ученая архивная комиссия, общество естествоиспытателей и любителей естествознания. Именно в этих обществах начинается систематическое изучение и сбор краеведческого материала по истории, географии, геологии и биологии Саратовской губернии. Следует отметить, что в период с конца XIX - начала $\mathrm{XX}$ в. флористические исследования Саратовского края получают широкое развитие. В некоторых флористических работах авторы не только описывают различные виды растений, но и предлагают охранять с помощью организации заповедников отдельные наиболее редкие виды.

Первой известной нам публикацией, касающейся вопроса организации заповедника в пределах Саратовской губернии, является доклад о флоре Саратовского уезда, прочитанный на заседании Ботанического общества Юго-Восточного края 10 декабря 1917 г. Дмитрием Ерастовичем Янышевским. В докладе говорится о необходимости создания небольшого заповедника в окрестностях Саратова. Он был напечатан впоследствии в журнале Русского ботанического общества и несколько позже в «Сельскохозяйственном вестнике Юго-Востока» [13].

Позднее в целом ряде публикаций, относящихся к 20-м гг. ХХ в., в «Известиях Саратовского общества естествоиспытателей» членами этого общества указывается на необходимость создания заповедных территорий в Саратовском крае. Так, в статье историка-краеведа Б.В. Зайковского «О вымерших и вымирающих представителях природы Нижне-волжской области» поднимается проблема исчезновения или сокращения популяции некоторых видов птиц и зверей, редких видов растений в окрестностях Саратова и в Заволжье [14]. В заключительной части статьи Б.В. Зайковский предлагает «...где только представится возможным и допустимым устраивать хотя бы небольшие заповедники, которые затем окупят себя сторицей» [14, с.56]. Наряду с Б.В. Зайковским «отрицательную динамику» отдельных видов растений отмечают и многие ботаники, занимавшиеся изучением флоры Саратовского края. Некоторые из них, как, например, В.Н. Чернов, К.Ю. Гросс и др., считали необходимым скорейшую организацию заповедников $[15,16]$. К.Ю. Гросс, в частности, отмечая исчезновение венериного башмачка в Хвалынском районе, предлагал «энергичнее содействовать на местах охране подобных памятников природы устройством небольших заповедников на наиболее примечательных флористических пунктах края» [16, с.106].

Особое место в исследовании территории Саратовского края и выявлении ценных природных объектов занимают экспедиции, организованные известным ботаником И.И. Спрыгиным. Им был создан первый в советской России заповедник - Пензенский [2]. Деятельность Спрыгина, направленная на поиск ценных природных объектов с последующей организацией в их пределах заповедников, вышла за пределы обширной территории бывшего Средневолжского края, затронув, в частности, северную часть территории Саратовского края. Отметим, что в двух экспедициях И.И. Спрыгина, частью проходивших на территории Саратовского края, активно принимали участие местные ботаники-краеведы, в том числе известный К.Ю. Гросс - основатель и директор Хвалынского краеведческого музея.

В 1927 г. под руководством И.И. Спрыгина состоялась экспедиция в Жигули [17]. Целью данной экспедиции было дальнейшее изучение Приволжской возвышенности, и в частности территории Жигулевского заповедника. Сначала экспедиция направилась в район Хвалынска, где к участникам экспедиции присоединился К.Ю. Гросс. Во время этой части экспедиции были обследованы меловые склоны в районе горшиханов Каланчи, Богданихи, Хреновских дач, Черемшанских скитов. Участники экспедиции указывали на особенности растительности исследованной территории, главными из которых были боры на мелу и на песках с разнообразной степной растительностью, а также участки чернолесья. По результатам проведенных исследований ими были подготовлены предложения по организации заповедника. Материалы по научному обоснованию организации заповедника были переданы в Нижневолжскую межведомственную комиссию по охране природы. Заповедный режим предлагали установить в окрестностях Черемшанских скитов (500 га), а также на участке близ Хреновских дач и на горах Каланча, Фокина шишка, Богданиха. Однако заповедник не был организован. В следующем, 1928 г., И.И. Спрыгин совершил экспедицию в Пугачевский и Бузулукский уезды [17]. В результате проведенных исследований в районе г. Пугачева были обнаружены небольшие участки целинных и старозалежных степей. В частности, был отмечен участок ковыльной степи площадью 
250 га в 25 км к юго-востоку от г. Пугачева по левому берегу р. Вязовка. Однако для заповедования был предложен участок ковыльно-типчаковой степи «Козявка», расположенный на р. Бузулук к югу от с. Ефимовка (Оренбургская область). В г. Пугачеве в работе экспедиции принимал участие И.И. Тереножкин - местный ботаник-краевед.

Итогом второго этапа можно считать образование некоторого количества охотничьих и видовых заказников. Организация первых государственных заказников происходит в 20-х гг. XX столетия. Заказники создавались губернскими и уездными органами власти. Так, например, были организованы заказники на территории Усовского, Сокурского, Большого Копенского лесничеств со сроком охраны три года, отдельным постановлением Петровского Уисполкома «Об охране дичи и заповедников» в Петровском уезде был организован, по существу, целый ряд бессрочных комплексных охотничьих заказников $[18,19]$.

Примечательно, что, несмотря на относительно широкую волну предложений организовать заповедники в степных ландшафтах либо на границе леса и степи, охраняемые природные территории организовываются в лесных ландшафтах. При этом основным критерием организации заказного режима становится охотопромысловая значимость территории.

Таким образом, первый период характеризуется созданием в Саратовской области двух типов ООПТ. Первый характерный тип ООПТ был направлен на сохранение отдельных видов охотничьих животных, второй ограничивал и регулировал лесопользование. На первом этапе в Саратовской области создавались отдельные частные заповедники-заказники, а также всевозможные лесные «заповеди». В последующем, с отменой частной собственности и национализацией всех земельных ресурсов, широкое распространение получают срочные и бессрочные государственные охотничьи заказники.

Второй период (50-90-е гг. XX в.), как указано выше, отражает процесс создания современной структуры региональной сети ООПТ Саратовской области. Начало этого периода связано с организацией и последующей деятельностью Саратовского отдела Всероссийского общества охраны природы (ВООП). Саратовский отдел ВООП был организован в 1947 году [20]. Первые шаги Саратовского отдела ВООП были мало связаны с организацией ООПТ. Однако в последующем роль общества охраны природы в организации, выявлении охраняемых природных территорий стала ключевой.

Первый этап (50-е гг. - начало 80-х гг. XX в.) второго периода характеризуется появлением нового интереса к особо охраняемым природным территориям, о котором можно судить по региональным научным публикациям того времени. В середине XX в., особенно в 60-70-е гг., появляются публикации о необходимости создания ООПТ, приводятся научные обоснования их создания. В некоторых публикациях прямо не говорится о необходимости создания какой-либо категории ООПТ, но приводятся перечни объектов и территорий, «заслуживающих всемерной охраны» [21, $22,23]$. Таким образом, авторами данных статей делается попытка на территории Саратовской области выделить особенные территории и объекты, являющиеся, по их мнению, «достопримечательностями живой природы». В последующем данные перечни, наряду с другими источниками, послужили основой для создания первого перечня памятников природы [24].

Обратимся к основным публикациям, имевшим наиболее важное значение в формировании подходов к выявлению ценных объектов и территорий с целью организации в них режима особой охраны. Хронологически одной из первых подобных работ является доклад профессора Саратовского госуниверситета геоботаника А.Д. Фурсаева, сделанный в 1947 г. на одном из заседаний правления Юго-Восточного филиала государственного Ботанического общества [25]. В докладной записке А.Д. Фурсаев отмечает «отсталость заповедования природы Саратовской области, несмотря на исключительную важность изучения природы в естественном состоянии...», и предлагает заповедать участки, имеющие достаточную площадь, исключающую влияние человека, а также высокую степень сохранности. Размер таких участков должен был составлять, по его мнению, 10х10 км. В записке говорится о необходимости сохранять «типичные элементы ландшафта Саратовской области и всего ЮгоВостока», которыми, как указывает А.Д. Фурсаев, являются лес, лесостепь, степь, поймы рек и места выходов меловых обнажений. В приведенном в докладной записке кратком перечне территорий, заслуживающих организации в их пределах заповедного режима, перечислены следующие земельные выделы: лес у с. Дьяковки-Салтово, степные участки в Пугачевском районе на территории конесовхоза и у с. Грязнухи Петровского района, массив дубрав у Хвалынска с сосняками и участками степи с меловыми обнажениями, овражный массив в пределах Базарно-Карабулакского района (около дороги на Вязовку). Поиск лесостепных участков, по мнению А.Д. Фурсаева, следует вести на территории Правобережья - в Самойловском, Татищевском, Казачкинском районах, где могут быть найдены «по существующим сведениям хорошие участки» [25].

Не рассматривая детально природные особенности указанных выше территорий, отметим, что подход к сохранению типичных ландшафтов Саратовской области, предложенный Фурсаевым, отражает её природные особенности на уровне природных зон и интразональных местностей.

В одной из последующих работ А.Д. Фурсаев предложил критерии сохранения флоры [25]. Разделив всю флору Саратовской области 
на 7 групп, 3 из которых - неохраняемые растения, остальные 4 группы с различной степенью необходимости охраны. К четырем охраняемым группам растений он отнес виды, имеющие разорванный ареал или находящиеся на границе своего ареала, эдемичные, реликтовые виды, отдельные старовозрастные деревья, различные виды древесных и кустарниковых экзотов. В последующем именно этот принцип - наличие редких видов, как естественной, так и интродуцированной флоры - стал ведущим при выявлении практически всех ООПТ Саратовской области (за исключением геологических). Редкие виды растений или, вернее, наличие их в определенных местообитаниях стали индикаторами, свидетельствующими о необходимости организации особо охраняемых природных территорий.

В этот период в саратовской географической литературе также начинают разрабатываться подходы к выявлению особо охраняемых территорий. Приоритет в постановке вопросов охраны природы и связанных с ними проблем ООПТ принадлежит кафедре физической географии географического факультета Саратовского госуниверситета. Данные проблемы активно разрабатывались с 1962 г. сначала М.А. Шабановым, а в последующем Л.В. Будигиной [26].

Остановимся на одной из главных работ Михаила Алексеевича Шабанова - его докторской диссертации, посвященной вопросам физико-географического районирования Саратовского Заволжья. В одной из глав - «Охрана и преобразование природы» - рассмотрены наиболее существенные для всего Саратовского Заволжья преобразования, связанные с ирригацией, строительством каналов, затоплением волжской поймы [28]. В разделе «Рекомендации по охране типичных ландшафтов» отмечается, что типичные ландшафты трансформированы и организация степных заповедников невозможна, так как вся территория распахана, возможна лишь организация степных заказников. Заказники, по мнению М.А. Шабанова, должны отражать основные типы ландшафтов на уровне подзон: северостепные, среднестепные и южностепные. Примерами таких участков, которые сохранили типичные, характерные черты указанных подзон, являются следующие территории: в пределах северостепной подзоны - урочище «Змейка» на водоразделе рр. Б. Иргиза и Чернавы, а также верховья оврага Таволожка, впадающего в Б. Иргиз; участок степи в истоках Б. Узеня - среднестепная подзона; южностепная подзона - островные участки полупустыни - Дьяковский лес с прилегающими участками сухой степи, лиманами, пойменными лесами р. Еруслан.

Для иллюстрации последующих публикаций, посвященных вопросам организации и выявлению ООПТ Саратовской области, приведем статьи Е.К. Кох и Л.В. Будигиной. В статье ботаника Е.К. Кох «Охрана флоры и растительности Саратовской области» [27] указывается на отсутствие заповедников на территории Саратовской области. В связи с этим охрана растений и растительности, по её мнению, должна осуществляться на основе организации заказников. Она выделяет восемь «элементов флоры», отражающих флористическое разнообразие территории Саратовской области и предлагает организовать с учетом данных особенностей охрану нуждающихся видов растений, в том числе на следующих территориях: Вольско-Хвалынский лесной массив со степными склонами, Дьяковский лес, урочище «Змейка» в Пугачевском районе, «Моховое» болото в Новобурасском районе [27].

В работе географа Л.В. Будигиной «Типичные ландшафты - под охрану» [28] сжато описываются природные особенности Саратовской области и отмечаются территории, характеризующие зональные и интразональные условия региона, где, по её мнению, и следует сохранять естественные природные ландшафты. Наряду с ранее отмеченными многими исследователями территориями Моховое болото, Вольско-Хвалынский лесной массив, Дьяковский лес и др. указываются еще территории в Александрово-Гайском районе, представляющие собой участки комплексной растительности с лиманами и падинами. В этой работе Л.В. Будигиной высказывается идея организации Заволжского степного заповедника в восточных районах Саратовского Заволжья.

Сведения о примечательных природных объектах из различных научных публикаций, а также научные обоснования организации охраняемых природных территорий концентрируются в Саратовском областном отделе Всероссийского общества охраны природы. Формируется обширный список территорий и объектов, обладающих, по мнению предлагавших его авторов, особой природной ценностью.

В 1976 г. начинает работу секция ООПТ Саратовского областного отдела ВООП, руководителем которой на протяжении многих лет являлась Л.В. Будигина ${ }^{1}$. С организации секции ООПТ началась не только работа по выявлению особо ценных территорий, но и практическая деятельность по законодательному закреплению их юридического статуса как особо охраняемых территорий. Несмотря на то, что выявление особо ценных территорий началось задолго до появления секции ООПТ [24], только благодаря целенаправленной деятельности членов этой секции стало возможным появление новой категории охраняемых природных территорий в Саратовской области - государственных памятников природы.

В 1979 г. в обобщающей работе Л.В. Будигиной «Охрана памятников природы Саратовской области» приводится список из 130 объектов [24]. Предложенный Л.В. Будигиной перечень

\footnotetext{
1 При написании статьи были использованы фондовые материалы Саратовского областного отделения Всероссийского общества охраны природы.
} 
объектов был составлен по архивным материалам Всероссийского обществ охраны природы, фондовым материалам управления лесного хозяйства и др. На основе этого перечня в 1982 г. облсовет Саратовской области принял Решение № 342, в котором все указанные объекты были признаны государственными памятниками природы [29]. В дальнейшем принятый перечень памятников природы подвергался изменениям, наиболее существенные из них произошли в 1991 и 1997 годах $[30,31]$. Таким образом, к концу первого этапа второго периода в Саратовской области наряду с охотничьими заказниками начинает действовать еще одна категория особо охраняемых территорий - памятники природы.

На первом этапе второго периода были сформулированы основные подходы к выявлению ООПТ, обозначился круг крупных территорий, имеющих, по мнению различных исследователей, исключительную ценность для сохранения типичного природного облика Саратовской области. Однако декларируемый подход к выявлению особо ценных территорий, учитывающий широтно-зональные условия региона, не был полностью реализован. Большая часть наиболее ценных, репрезентативных в ландшафтно-географическом смысле территорий осталась незащищенной законодательно. Этот факт подтверждается содержанием первого перечня объектов и территорий, взятых под охрану в качестве государственных памятников природы. Так, многие из объектов перечня являются интродуцентами либо имеют искусственное происхождение, из естественных памятников природы абсолютное доминирование принадлежит лесным ландшафтам.

Второй этап (80-90-е гг. XX в.) характеризуется еще большим повышением общественного интереса к охране природы. В эти годы публикуется относительно большое количество краеведческой природоохранной литературы, в том числе и научно - популярного жанра. Среди научно-популярных изданий, посвященных охране природы и частью затрагивающих проблемы охраняемых природных территорий, наибольший интерес представляют следующие: «Места заповедные», «За голубым тюльпаном», «Опасайтесь потерять друзей» $[32,33,34]$. В частности, в последней книге [34] обосновывается необходимость организации двух национальных парков - Саратовского и Хвалынского, Заволжского степного заповедника, целого ряда ландшафтных и ботанических заказников. Среди научных публикаций особо отметим публикацию ботаников И.Б. Миловидовой, В.Г. Мичурина и др. [35], в которой указаны 54 объекта с кратким описанием их ценности. В статье авторами предлагается разделить данные объекты по существующим на тот период категориям ООПТ [35].

В начале 80-Х гг. ХХ в. ВООП разворачивает работу по выявлению, паспортизации и законодательному закреплению памятников природы, про- исходит многократное изменение части перечня памятников природы, принятого в 1982 году [36, $37,38]$. В этой работе принимает участие широкий круг общественности, различные организации и учреждения, в том числе Саратовский государственный университет, Саратовский педагогический институт, ГОСНИИОРХ, районные советы ВООП, райисполкомы и др. [39]. Инициатива организации памятников природы большей частью исходила от ученых Саратовского государственного университета, Саратовского педагогического института, однако не менее важную роль в организации и становлении региональной сети ООПТ сыграли отдельные активисты районных организаций ВООП. Особо заметна деятельность по организации и выявлению памятников природы ботаника-краеведа В.В. Брехова, руководителя отдела природы Вольского краеведческого музея. Им были не только подготовлены научные обоснования на все существующие в Вольском районе памятники природы, но и фактически осуществлялся контроль за выполнением охранного режима на этих территориях. Таким образом, структура районных сетей ООПТ во многом определялась деятельностью отдельных активистов природоохранного движения.

В последующем результаты работы ВООП по выявлению и организации памятников природы перетерпели значительные изменения. Так, в 1997 г. некоторые памятники природы были необоснованно исключены из перечня 1991 г., составленного обществом охраны природы, у большинства памятников природы была изменена конфигурация границ либо местоположение.

Пик активности в сфере организации ООПТ приходится на середину 80-х - начало 90-х гг. XX века. В 1986 г. принимается Решение № 207 о создании первого в Саратовской области биологического заказника республиканского значения «Дьяковский» [40]. Однако фактическое образование биологического заказника так и не произошло. Следует отметить, что Дьяковский лес в середине 80-х гг. рассматривался государственными органами управления как территория под заповедник, но из-за отсутствия, по нашему мнению, четкой программы перехода от ликвидации убыточного лесхоза к созданию природоохранного учреждения этого не произошло. В начале 90-х гг. широко обсуждается вопрос о создании двух национальных парков: Саратовского и Хвалынского. В результате в 1992 г. создается природный парк «Хвалынский» [41]. В 1994 г. он получает федеральный статус и становится национальным парком. Расширяется сеть охотничьих заказников. К 1995 г. существовало 25 заказников областного значения общей площадью 394,1 тыс. га [41]. Максимальной площади заказники Саратовской области достигли в 2001 г., которая составила 499,4 тыс. га [42]. Однако в 2003 г. из-за очередного преобразования органов управления региональными ООПТ охотничьи заказники были 
реорганизованы. В настоящий момент в Саратовской области действует один заказник федерального значения - «Саратовский» [43].

Главным итогом второго периода следует считать окончательное образование современной структуры региональной сети ООПТ, основными элементами которой стали памятники природы, заказники и национальный парк «Хвалынский».

Рассмотренные периоды и этапы формирования региональной сети ООПТ Саратовской области демонстрируют ряд характерных черт сложившейся сети охраняемых природных территорий. Во-первых, в подходах к выявлению ООПТ преобладал ботанический подход, определивший современную структуру ООПТ региона. В связи с чем в структуре региональной сети охраняемых природных территорий возникла некоторая односторонность и внесистемность, выражающаяся в крайне низкой ландшафтно-географической репрезентативности объектов сети ООПТ [44]. Так, например, основная категория ООПТ Саратовской области - памятники природы представлены большей частью фрагментами лесных геосистем (78\% области занято степями). Почти половина действующих памятников природы имеет искусственное происхождение (насаждения экзотов, искусственные лесные насаждения и т.д.). Во-вторых, на протяжении всей истории формирования сети ООПТ Саратовской области отсутствовали крупные территории со строгим заповедным режимом охраны, позволяющим сохранять значительные по размеру природные комплексы. Таким образом, следует признать недопустимо малую роль сложившейся сети ООПТ по сохранению ландшафтного и биологического разнообразия Саратовской области.

Современное состояние сети ООПТ Саратовской области показывает, что, несмотря на многократное увеличение антропогенной нагрузки на территорию региона с конца XIX в., а также развитие концепции организации охраняемых природных территорий и совершенствование законодательной базы в сфере ООПТ, развитие региональной сети ООПТ происходит чрезвычайно медленно. Сеть охраняемых природных территорий Саратовской области находится на первой затянувшейся стадии развития - формирования отдельных объектов сети ООПТ.

С середины 90-х гг. прошлого века не проводились специальные исследования по изучению и выявлению ООПТ региона, количество ранее проводимых исследований также следует признать недостаточным. В результате этого практически полностью отсутствует информация о современном состоянии региональных охраняемых природных территорий и выполнении особого режима их охраны.

Отметим, что в последние годы наметился перелом в подходах к управлению региональной сетью ООПТ Саратовской области и их организации. Начиная с 2004 г. Саратовским госунивер- ситетом и Комитетом охраны природы и природопользования Саратовской области проводится инвентаризация ООПТ региона.

Автор выражает глубокую признательность зам. председателя Саратовского областного отдела Всероссийского общества охраны природы О.И. Кайоте за предоставленные архивные материалы, а также канд. биол. наук И.Б. Миловидовой за неоченимую консультативную помощьь.

\section{Библиографический список}

1. Идея абсолютной заповедности. Помни праотцов - заповедного не тронь! / Сост. В.Е. Борейко. М., 2005. $116 \mathrm{c}$.

2. Реймерс Н.Ф., Штильмарк Ф.Р. Особо охраняемые природные территории. М., 1978. 297 с.

3. О правилах охоты на территории области и об утверждении перечня заказников и охотничьих хозяйств: Решение № 585 Саратовского облисполкома от 2.12.1966 г. // ГАСО. Ф.1738, оп. 4, ед. хр. № 369, лл. 7-39.

4. Особо охраняемые природные территории Российской Федерации (Статистический сборник) / Под ред. А.Д. Думнова, Н.Г. Рыбальского. М., 2003. 141 с.

5. Протокол заседания Саратовского общества естествоиспытателей и любителей естествознания от 25 ноября 1900 г. // Тр. Саратовского о-ва естествоиспытателей и любителей естествознания. Саратов, 1901. Т. ІІІ, вып. 1. С. 4-10.

6. Пады - имение В.Л. Нарышкина. Естественно-исторический очерк / Под ред. В.В. Докучаева. СПб., 1894. 437 с.

7. Талиев В.И. К флоре Саратовской губернии // Протоколы заседаний общества естествоиспытателей при Казанском ун-те 1897-1898 гг. Казань. Т. 29. Приложение № 174. C. 1-7.

8. Очерки по истории Саратовского Поволжья (18941917): В 2 т. / Под ред. И.В. Пороха. Саратов, 1999. Т. 2 , ч. $2.432 \mathrm{c}$.

9. Келлер Б.А. Ботанико-географические исследования в Саратовской губернии // Тр. о-ва естествоиспытателей при Императорском Казанском университете. Казань, 1901. Т. 35, вып. 4. 180 с.

10. Лакин Г.И. Леса Волжского займища // Сельскохозяйственный вестн. Юго-Востока. 1914. №15. С. 32-34.

11. Гладков Н.А. Охрана природы в первые годы советской власти. М., 1972. 35 с.

12. Захаров В.М., Миронов В.Г. У истоков Саратовского исторического краеведения // Тр. Саратовского историкокраеведческого о-ва. Саратов, 1992. Вып. 2. С. 78-99.

13. Янышевский Д.Е. К флоре Саратовского уезда // Сельскохозяйственный вестн. Юго-Востока. 1918. № 3-5. C. 30-33.

14. Зайковский Б.В. О вымерших и вымирающих представителях природы Нижне-Волжской области // Тр. Нижне-Волжского обл. науч. о-ва краеведения. Саратов, 1925. Вып. 34, ч. 3. С. 52-56.

15. Чернов В.Н. К флоре Вольского уезда Саратовской области // Тр. Саратовского о-ва естествоиспытателей и любителей естествознания. Саратов, 1927. Т. 11, вып. 1. C. 47-51. 
16. Гросс К.Ю. Материалы по меловой флоре Саратовской губернии: Crambe Litwinowi Gross. Катран приволжский // Известия Саратовского о-ва естествоиспытателей. Саратов, 1928. Т. ІІ, вып. 2. С. 105-108.

17. Спрыгина Л.И. Иван Иванович Спрыгин (1873-1942). M., $1982.176 \mathrm{c}$.

18. ГАСО. Ф.1166, оп.1, ед. хр. № 252, лл. 16.

19. Там же. Ф.521, оп.1, ед. хр. № 752, лл. 164.

20. Там же. Ф.2650, оп.1, ед. хр. № 615, лл. 26-28.

21. Рубанов М.Н. Особо ценные лесные насаждения // Природа и люди. Саратов, 1976. С. 145-150.

22. Миловидова И.Б. Дендрологические редкости // Там же. С. $159-169$.

23. Девишев Р.А., Чекрыгина В.С., Свириденко В.Т. Достопримечательности живой природы // Природа родного края и её охрана. Саратов, 1971. С. 232-246.

24. Будигина Л.В. Охрана памятников природы Саратовской области // Вопросы истории и теории физической географии. Саратов, 1979. Вып. 5(12). С. 81-100.

25. Фурсаев А.Д. Объекты растительного покрова Саратовской области, подлежащие охране // Охрана природы и озеленение населенных пунктов: Материалы VI Bceуральского совещания по вопросам географии и охраны природы. Уфа, 1961. С. 71-76.

26. Алексеевская Н.К., Добрина Н.Д., Макаров В.3. История развития кафедры физической географии и ландшафтной экологии // Развитие физической географии и ландшафтной экологии в Саратовском университете / Под ред. д-ра геогр. наук, проф. В.З. Макарова. Саратов, 2005. C. 6-26.

27. Кох E.К. Охрана флоры и растительности Саратовской области // Экологические и фитоценотические исследования на Юго-Востоке Европейской части СССР. Саратов, 1973. C. 89-94.

28. Будигина Л.В. Типичные ландшафты - под охрану // Природа и люди. Саратов, 1976. С. 223-227.

УДК $913(470.44)+002: 001+577.4$

\section{НЕКОТОРЫЕ РЕЗУЛЬТАТЫ ЛАНДШАФТНО-ЭКОЛОГИЧЕСКИХ ИССЛЕДОВАНИЙ НА ТЕРРИТОРИИ ХВАЛЫНСКОГО НАЦИОНАЛЬНОГО ПАРКА}

\author{
В.3. Макаров, А.Н. Чумаченко', В.А. Данилов, \\ Ю.В. Волков, А.В. Федоров 1
}

Саратовский государственный университет, кафедра физической географии и ландшафтной экологии, 1 кафедра геоморфологии и геоэкологии E-mail: urbolab@sgu.ru

В статье изложены современные проблемы организации научной работы в Хвалынском национальном парке. Рассмотрена программа ландшафтно-экологических исследований в Парке. Приводятся некоторые результаты ландшафтно-геохимических работ и снегомерной съемки в центральной части Парка. Изучаются перспективы дальнейших исследований с применением ГИС-технологий.
29. ГАСО. Ф. 1738, оп. 8-пр., ед. хр. № 1963, лл. 137-146. Об утверждении перечня памятников природы местного значения: Решение Саратовского облисполкома от 15.07.82 г. № 342 .

30. Там же. Ед. хр. № 3177, лл. 125-152. Об утверждении перечня государственных памятников природы: Решение Саратовского облисполкома от 27.12.91 г. № 328 .

31. Об утверждении Перечня памятников природы регионального значения в Саратовской области: Постановление губернатора Саратовской области от 21.04.97 г. № 321 // СПС «КонсультантПлюс».

32. Места заповедные: Сб. очерков / Ред., сост. Л.А. Розанова. Саратов, $1981.79 \mathrm{c}$.

33. Никитина О.В. За голубым тюльпаном: Сб. очерков. Саратов, 1989. $120 \mathrm{c}$.

34. Опасайтесь потерять друзей: Очерки об охране природы Саратовской области. Саратов, 1983. $112 \mathrm{c}$.

35. Чигуряева А.А., Лебедев В.А., Миловидова И.Б., Мичурин В.Г. Подлежащие охране ботанические объекты Саратовской области // Вопросы ботаники Юго-Востока. Саратов, 1988. С. 3-30.

36. ГАСО. Ф. 1738 , оп. 8-пр., ед. хр. № 2453 , лл. 6.

37. Там же. Ед. хр. № 3010, лл. 50-52.

38. Там же. Ед. хр. № 3027, лл. 57-62.

39. Будигина Л.В. Объекты редкие и ценные: памятники природы // Коммунист (Саратов). 1984. 20 апр. № 91, 4 с.

40. ГАСО. Ф. 1738, оп. 8-пр., ед. хр. № 2628, лл. 98.

41. Там же. Оп. 2, ед. хр. № 2208, лл. 11-15.

42. Состояние окружающей среды и природных ресурсов Саратовской области в 2000 г. Саратов, 2001. 160 с.

43. Доклад о состоянии и об охране окружающей среды Саратовской области в 2004 г. Саратов, 2005. 158 с.

44. Волков Ю.В. Сеть особо охраняемых природных территорий Саратовской области в ландшафтной структуре региона // Изв. Сарат. ун-та. Новая серия. 2004. Т. 4, вып. 1-2. C. $167-174$.
Some Results of Landscape-ecological Researches on Territory Hvalynsky National Park

\section{V.Z. Makarov, A.N. Chumachenko, V.A. Danilov, Yu.V. Volkov, A.V. Fedorov}

In article modern problems of the organization of scientific work in Hvalynsky national park are stated. The program of landscapeecological researches in Park is considered. Some results of landscapegeochemical works and snow shootings in the central part of Park are proofs. Prospects of the further researches with application of GIS-technologies are studed. 